\title{
Effect of injection depth of digestate liquid fraction on soil carbon dioxide emission and maize biomass production
}

\author{
Carmelo Maucieri, ${ }^{1}$ Antonio C. Barbera, ${ }^{2}$ Maurizio Borin ${ }^{1}$ \\ 'Department of Agronomy, Food, Natural Resources, Animals and Environment, University \\ of Padua, Legnaro (PD); ${ }^{2}$ Department of Agriculture, Food and Environment, University of \\ Catania, Catania, Italy
}

\begin{abstract}
The aim of this study was to evaluate, in open field conditions, the effect of injection depth of digestate liquid fraction $(10 \mathrm{~cm}, 25 \mathrm{~cm}$ and $35 \mathrm{~cm}$ ) in clay loam soil, on $\mathrm{CO}_{2}$ emission. An un-amended soil was considered as control. The study was performed in 2014 on a farm located in Terrasa Padovana, Veneto region (Italy) distributing digestate before maize sowing.

Digestate injection determined a high soil $\mathrm{CO}_{2}$ emission in the first hour after application, followed by a progressive reduction in as early as $24 \mathrm{~h}$, reaching significantly lower values, similar to those measured in the un-amended control, after $48 \mathrm{~h}$. Gas emissions measured $1 \mathrm{~h}$ after digestate application decreased as injection depth increased with significantly higher emission values in the $10 \mathrm{~cm}$ treatment (median value $23.7 \mathrm{~g} \mathrm{CO}_{2} \mathrm{~m}^{-2} \mathrm{~h}^{-1}$ ) than in the $35 \mathrm{~cm}$ one (median value $2.5 \mathrm{~g}$ $\mathrm{CO}_{2} \mathrm{~m}^{-2} \mathrm{~h}^{-1}$ ). In the 3 days between digestate distribution and maize sowing, soil $\mathrm{CO}_{2}$ emission was significantly higher in the amended treatments than un-amended one, with median values of $1.53 \mathrm{~g} \mathrm{CO}_{2}$ $\mathrm{m}^{-2} \mathrm{~h}^{-1}$ and $0.46 \mathrm{~g} \mathrm{CO}_{2} \mathrm{~m}^{-2} \mathrm{~h}^{-1}$ respectively. During maize growing season, no significant soil $\mathrm{CO}_{2}$ emission difference was monitored among
\end{abstract}

Correspondence: Carmelo Maucieri, Department of Agronomy, Food, Natural Resources, Animals and Environment (DAFNAE), University of Padua, Agripolis Campus, viale dell'Università 16, 35020 Legnaro (PD), Italy.

E-mail: carmelo.maucieri@hotmail.it

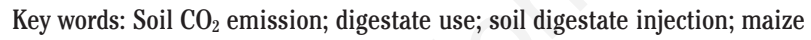
biomass yield.

Acknowledgements: the research is supported by ValDige project Valorizzazione del digestato per la riduzione delle perdite $\mathrm{di}_{2} \mathrm{CO}_{2}$ DGR $\mathrm{n}^{\circ} 1604$ del 31/07/2012 financed by PSR Regione Veneto (2007-2014) misura 124, Domanda n. 2307827.

Conference presentation: SIA XLIII Congress, Pisa, 2014.

Received for publication: 29 January 2015.

Revision received: 17 June 2015.

Accepted for publication: 7 August 2015.

(C) Copyright C. Maucieri et al., 2016

Licensee PAGEPress, Italy

Italian Journal of Agronomy 2016; 11:657

doi:10.4081/ija.2016.657

This article is distributed under the terms of the Creative Commons Attribution Noncommercial License (by-nc 4.0) which permits any noncommercial use, distribution, and reproduction in any medium, provided the original author(s) and source are credited. treatments, with a median value of $0.33 \mathrm{~g} \mathrm{CO}_{2} \mathrm{~m}^{-2} \mathrm{~h}^{-1}$.

Digestate application significantly improved maize aboveground dry biomass with an average yield of $22.0 \mathrm{Mg} \mathrm{ha}^{-1}$ and $16.2 \mathrm{Mg} \mathrm{ha}^{-1}$ in amended and un-amended plots, respectively, due to the different amount of nutrients supplied.

\section{Introduction}

Intensive soil fertilisation with mineral fertilisers has led to several issues, like loss of soil carbon (C), and nitrogen (N) leaching (Borin et al., 1997; Nardi et al., 2004; Morari et al., 2006). Fertilisation with organic wastes therefore represents an alternative for sustainable agriculture (Casacchia et al., 2012; Marchetti et al., 2012; Morra et al., 2013; Barbera et al., 2013; Nkoa, 2014). In this context the agricultural reuse of digestate, organic waste product of biogas plants, should be considered. Furthermore, the sustainability of biogas production may depend on an appropriate end-use of the downstream effluents of anaerobic digestion, which should be treated, disposed of, or re-used in a proper way, avoiding any environmental impact (de la Fuente $e t$ al., 2013). Digested waste materials present some advantages for their use as soil amendments in comparison with untreated wastes, such as greater microbial stability and hygiene and a higher $\mathrm{NH}_{4}{ }^{+}-\mathrm{N}$ amount (Holm-Nielsen et al., 2009; Alburquerque et al., 2012b; Möller and Müller, 2012). Therefore, digestate can be considered as organic amendment or organic fertiliser when properly handled and managed (Nkoa, 2014). In fact, the application of organic matter to agricultural soils stimulates microbial activity, increasing greenhouse gases emission (Bol et al., 2003; Fangueiro et al., 2010), thus requiring the application of appropriate agronomic techniques for greenhouse gases emission mitigation (Pezzolla et al., 2012).

Several laboratory scale studies investigated the effect of soil amendment with digestate on $\mathrm{CO}_{2}, \mathrm{CH}_{4}$ and $\mathrm{N}_{2} \mathrm{O}$ emissions (Cayuela et al., 2010; Grigatti et al., 2011; Sänger et al., 2011; Alburquerque et al., 2012a; de la Fuente et al., 2013; Johansen et al., 2013). A limited number of studies reported results obtained in open field conditions, mainly focusing on $\mathrm{CH}_{4}, \mathrm{~N}_{2} \mathrm{O}$ and $\mathrm{NH}_{3}$ emissions, comparing the effect of anaerobically digested and undigested slurries or different digestate soil distribution techniques (Rubæk et al., 1996; Petersen, 1999; Wulf et al., 2002; Dieterich et al., 2012). Only a few open field studies investigated soil $\mathrm{CO}_{2}$ emission after digestate application, spreading it on grassland (Pezzolla et al., 2012) or maize (Bachmann et al., 2014). To our knowledge, no field experiment has been conducted to evaluate soil $\mathrm{CO}_{2}$ emission after digestate injection at different soil depths.

Given the current knowledge, the aim of this work was to evaluate, in clay loamy soil, the effect of digestate liquid fraction (DLF) injection depth on $\mathrm{CO}_{2}$ emission and maize biomass production. 


\section{Materials and methods}

\section{Site description and experimental design}

The study was performed in 2014 on a farm located in Terrasa Padovana $\left(45^{\circ} 15^{\prime} \mathrm{N} 11^{\circ} 55^{\prime} \mathrm{E}, 1 \mathrm{~m}\right.$ a.s.l.), Veneto Region, Italy, on a clay loamy soil (USDA classification) after winter wheat (Triticum aestivum L.) aerial biomass harvested at dough stage. The effect of DLF injection depth on soil $\mathrm{CO}_{2}$ emission was studied through four treatments: no digestate distribution (ND), digestate injection with $1 \mathrm{~m}$ width between two injection nozzles at $10 \mathrm{~cm}$ depth $(10 \mathrm{~cm}), 25 \mathrm{~cm}$ depth $(25$ $\mathrm{cm})$ and $35 \mathrm{~cm}$ depth $(35 \mathrm{~cm})$. A randomised block design with three replicates and experimental plots of $500 \mathrm{~m}^{2}$ was used. DLF, obtained from anaerobic digestion of cattle slurry and manure, maize silage and flour, was distributed in the soil by injection technique on June 3 in a volume to obtain a total nitrogen supply of $170 \mathrm{~kg} \mathrm{ha}^{-1}$. The main chemical DLF characteristics, determined in three samples before the spreading operation, are reported in Table 1 . $\mathrm{N}$ fertilisation was integrated adding $50 \mathrm{~kg} \mathrm{~N} \mathrm{ha}^{-1}$ as urea during mechanical weed control, at fifth leaf phenological stage. The same urea dose was distributed in the un-amended plots to highlight the DLF effect. The DLF distribution added also $32.6 \mathrm{~kg} \mathrm{P}_{2} \mathrm{O}_{5} \mathrm{ha}^{-1}, 170.1 \mathrm{~kg} \mathrm{~K}_{2} \mathrm{O}$ ha $^{-1}$.

Distribution was carried out in undisturbed soil (June 3); after $23 \mathrm{~h}$ and $45 \mathrm{~h}$, respectively, a cultivation (25 $\mathrm{cm}$ depth) and harrowing (power harrow, $20 \mathrm{~cm}$ depth) were carried out to prepare the seedbed, and on June 6 maize (Zea mays L., Hybrid Pioneer P0837; FA0 400) was sown as second crop after winter wheat at a density of 7.5 seeds $\mathrm{m}^{-2}$.

\section{Soil $\mathrm{CO}_{2}$ flux measurement}

$\mathrm{CO}_{2}$ flux was measured with the static non-stationary chamber technique (Maucieri et al., 2014) using a chamber with a volume of $5 \mathrm{~L}$ and $10 \mathrm{~cm}$ square base.

$\mathrm{CO}_{2}$ emissions were detected in three points of each experimental plot in order to replicate the measures in the space with 9 measures for each studied treatment. After DLF distribution, soil $\mathrm{CO}_{2}$ emission was measured 3 times before maize sowing (after $1 \mathrm{~h}$ in undisturbed soil and after 24 and $48 \mathrm{~h}$, soon after the two tillage interventions), and 9 times after this (from 1 to 104 days) at regular intervals of about 13 days. Soil $\mathrm{CO}_{2}$ flux was determined by measuring the temporal change in $\mathrm{CO}_{2}$ concentration inside the chamber using a portable infrared instrument (Geotech G150; Geotechnical Instruments Ltd., Royal Leamington $\mathrm{Spa}, \mathrm{UK}$ ), detecting $\mathrm{CO}_{2}$ concentrations at levels of parts per million.

Table 1. Digestate chemical characteristics (mean value \pm standard deviation).

\begin{tabular}{lc}
\hline Parameters & Values \\
Dry matter \% & $6.4 \pm 0.3$ \\
$\mathrm{C} / \mathrm{N}$ ratio & $9.2 \pm 0.2$ \\
\hline $\mathrm{TKN}\left(\mathrm{mg} \mathrm{kg}^{-1} \mathrm{FM}\right)$ & $2936.7 \pm 8.7$ \\
$\mathrm{NH}_{4}-\mathrm{N}\left(\mathrm{mg} \mathrm{kg}^{-1} \mathrm{FM}\right)$ & $28.0 \pm 0.9$ \\
\hline $\mathrm{NO}_{3}-\mathrm{N}\left(\mathrm{mg} \mathrm{kg}^{-1} \mathrm{FM}\right)$ & $3.0 \pm 0.6$ \\
$\mathrm{P}\left(\mathrm{mg} \mathrm{kg}^{-1} \mathrm{FM}\right)$ & $246.1 \pm 9.2$ \\
\hline $\mathrm{K}\left(\mathrm{mg} \mathrm{kg}^{-1} \mathrm{FM}\right)$ & $2438.9 \pm 14.3$ \\
$\mathrm{Ca}\left(\mathrm{mg} \mathrm{kg}^{-1} \mathrm{FM}\right)$ & $621.0 \pm 8.5$ \\
\hline $\mathrm{Na}\left(\mathrm{mg} \mathrm{kg}^{-1} \mathrm{FM}\right)$ & $268.7 \pm 2.2$ \\
$\mathrm{Mg}\left(\mathrm{mg} \mathrm{kg}^{-1} \mathrm{FM}\right)$ & $235.0 \pm 7.5$ \\
\hline $\mathrm{C} / \mathrm{N}$, carbon/nitrogen ratio; TKN, total Kjeldahl nitrogen; $\mathrm{FM}$, fresh matter; $\mathrm{NH} \mathrm{N}_{4}-\mathrm{N}$, ammonium nitrogen;
\end{tabular}

$\mathrm{CO}_{2}$ flux was calculated using the following formula:

$$
C O_{2}=\frac{V}{A} \cdot \frac{d c}{d t}
$$

where $\mathrm{CO}_{2}$ flux is expressed in $\mathrm{mg} \mathrm{CO}_{2} \mathrm{~m}^{-2} \mathrm{~s}^{-1} ; \mathrm{V}\left(\mathrm{m}^{3}\right)$ is the volume and $\mathrm{A}\left(\mathrm{m}^{2}\right)$ the footprint of the flux chamber; $c$ is the $\mathrm{CO}_{2}$ concentration (mg CO $\mathrm{m}^{-3}$ ) and $t$ the time step (s).

In each $\mathrm{CO}_{2}$ measurement point, soil temperature and moisture (TDR 100 Soil Moisture Meter; Spectrum Technologies, Aurora, IL, USA) in the first $7.5 \mathrm{~cm}$ were also detected.

In maize-grown soil, $\mathrm{CO}_{2}$ fluxes measured between 9:00 and 12:00 a.m. can represent the mean $\mathrm{CO}_{2}$ daily emissions (Rochette and Flanagan, 1997; Lou et al., 2003; Ding et al., 2006). In view of this, in our study soil $\mathrm{CO}_{2}$ emission measures were carried out between these hours during the whole monitoring. Based on soil $\mathrm{CO}_{2}-\mathrm{C}$ fluxes, the mean cumulative soil $\mathrm{CO}_{2}$-C emission for each treatment, during both distribution phase and maize growing season, were calculated by summing the products of the average of two neighbouring measurement fluxes by their interval time. To compare cumulative soil $\mathrm{CO}_{2}-\mathrm{C}$ emission with the amount of $\mathrm{C}$ supplied to the soil by DLF, the cumulative $\mathrm{CO}_{2}-\mathrm{C}$ emission value monitored in the ND treatment was subtracted from those calculated for each amended treatment.

\section{Maize biomass measurement}

Maize aboveground biomass was harvested on September $26^{\text {th }}$ at dough stage. In each experimental plot, fresh biomass production was measured in four points (each $1.5 \times 4 \mathrm{~m}$ ) for a total 12 replicated production areas per treatment. Areas were randomly selected and maize plants were manually cut at $10 \mathrm{~cm}$ from soil. Biomass dry weight was determined by drying plant tissue samples in a thermo-ventilated oven at $65^{\circ} \mathrm{C}$ until constant weight was reached.

\section{Statistical analysis}

The normality of $\mathrm{CO}_{2}$ data was checked using the KolmogorovSmirnov test; due to the fact that they did not show normal distribution, the Kruskal-Wallis and Mann-Whitney non-parametric tests were used to check the significance of differences. Correlation between soil temperature and moisture with $\mathrm{CO}_{2}$ emissions were evaluated using Spearman Rank correlation.

Statistical analysis of biomass production and cumulative $\mathrm{CO}_{2}-\mathrm{C}$ emission was conducted by one-way analysis of variance (ANOVA); mean values were compared using Fisher least significant difference test at $\mathrm{P}<0.05$.

\section{Results and discussion}

\section{Soil $\mathrm{CO}_{2}$ emissions}

The DLF effect on soil $\mathrm{CO}_{2}$ emission followed the same trend in all three injection depths with a high $\mathrm{CO}_{2}$ emission in the first hour after application, followed by a rapid significant reduction as early as $24 \mathrm{~h}$, reaching values similar to those measured in the un-amended control after $48 \mathrm{~h}$ (Figure 1).

Considering the $\mathrm{CO}_{2}$ emission trend in the $48 \mathrm{~h}$ after injection, our data are in line with studies carried out in laboratory conditions by Sänger et al. (2011), who monitored a rapid soil $\mathrm{CO}_{2}$ production increase after biogas slurry application, and Grigatti et al. (2011) who reported, after digestate application, a very intensive $\mathrm{CO}_{2}$ emission in the first $24 \mathrm{~h}$ of soil incubation, followed by a reduction to a value close 
to the control. de la Fuente et al. (2013), again in a laboratory study, monitored a rapid soil $\mathrm{CO}_{2}$ emission decrease in the days after liquid digestate application and, after three weeks, $\mathrm{CO}_{2}$ emission values similar to those measured in the control soil. High $\mathrm{CO}_{2}$ soil flux in the first hour after distribution was likely due to both the release of $\mathrm{CO}_{2}$ dissolved in the digestate, and the rapid microorganism respiration of easily degradable C. In fact, as reported by Johansen et al. (2013), digested residues from biogas production induced only small and transient changes on the total soil microbial biomass, function and community structure. Focusing on the emissions measured $1 \mathrm{~h}$ after DLF injection, $\mathrm{CO}_{2}$ flux decreased when injection depth increased, with significantly higher emission value in the $10 \mathrm{~cm}$ treatment (median value $23.7 \mathrm{~g} \mathrm{CO}_{2}$ $\mathrm{m}^{-2} \mathrm{~h}^{-1}$ ) and the lowest one in the $35 \mathrm{~cm}$ treatment (median value 2.5 $\mathrm{g} \mathrm{CO}_{2} \mathrm{~m}^{-2} \mathrm{~h}^{-1}$ ) (Figure 2).

On the average of the 3 days between DLF distribution and maize sowing, soil $\mathrm{CO}_{2}$ emission was significantly higher (Mann-Whitney test, $\mathrm{P}<0.0006)$ in the three amended treatments than un-amended one with median values of $1.53 \mathrm{~g} \mathrm{CO}_{2} \mathrm{~m}^{-2} \mathrm{~h}^{-1}$ and $0.46 \mathrm{~g} \mathrm{CO}_{2} \mathrm{~m}^{-2} \mathrm{~h}^{-1}$ in the two respective cases. Data are in agreement with Pezzolla et al. (2012) and Johansen et al. (2013), who reported, in an open field and laboratory experiment, respectively, that after digestate application soil $\mathrm{CO}_{2}$ emission increased. Focusing on treatments, a significantly higher $\mathrm{CO}_{2}$ emission (Kruskal-Wallis, $\mathrm{P}<0.05$ ) was detected in the plots where DLF was injected into the soil at a lesser depth $(10 \mathrm{~cm}$ and $25 \mathrm{~cm})$; no significantly different emission was found between $35 \mathrm{~cm}$ and ND treatments (Figure 3).
The soil tillage with cultivator, done $20 \mathrm{~h}$ after DLF application in all treatments, did not exert a significant effect on soil $\mathrm{CO}_{2}$ emission measured $24 \mathrm{~h}$ after distribution. Instead, the harrowing ( $45 \mathrm{~h}$ after DLF application) determined a significantly higher $\mathrm{CO}_{2}$ emission (Kruskal-Wallis test, $\mathrm{P}<0.05$ ) at $48 \mathrm{~h}$ measures in the amended treatments (median value $0.58 \mathrm{~g} \mathrm{CO}_{2} \mathrm{~m}^{-2} \mathrm{~h}^{-1}$ ) than un-amended one (median value $0.22 \mathrm{~g} \mathrm{CO}_{2} \mathrm{~m}^{-2} \mathrm{~h}^{-1}$ ), although absolute median values were lower than those measured in the first two measurements. The significant effect of harrowing on $\mathrm{CO}_{2}$ emission can be due to both: i) the higher oxygen availability in the first soil layer because of the increase in soil macroporosity, which stimulates aerobic microbial populations; ii) the higher digestate physical accessibility for microorganisms and extracellular enzymes activities (Paustian et al., 2000).

During maize growing season, no significant difference in soil $\mathrm{CO}_{2}$ emission was monitored among treatments (Figure 4) with a median value of $0.33 \mathrm{~g} \mathrm{CO}_{2} \mathrm{~m}^{-2} \mathrm{~h}^{-1}$.

The DLF distribution applied $156.4 \mathrm{~g} \mathrm{~m}^{-2}$ of $\mathrm{C}$ to soil. A significantly higher cumulative soil $\mathrm{CO}_{2}-\mathrm{C}$ emission during the experimental period was found for $10 \mathrm{~cm}$ and $25 \mathrm{~cm}$ treatments, with an average value of $411.8 \pm 63.6 \mathrm{~g} \mathrm{CO}_{2}-\mathrm{C} \mathrm{m}^{-2}$; no significant difference was found between $35 \mathrm{~cm}$ and ND treatments, with an average value of $301.3 \pm 49.0 \mathrm{~g} \mathrm{CO}_{2^{-}}$ $\mathrm{C} \mathrm{m}^{-2}$ (Figure 5).

Comparing cumulative soil $\mathrm{CO}_{2}-\mathrm{C}$ emission with the amount of $\mathrm{C}$ supplied to the soil by DLF, until maize sowing the highest percent value was detected in the $10 \mathrm{~cm}$ treatment with a $61.4 \%$ emission of supplied C, followed by the $25 \mathrm{~cm}(43.8 \%)$ and $35 \mathrm{~cm}(2.2 \%)$ treat-
A

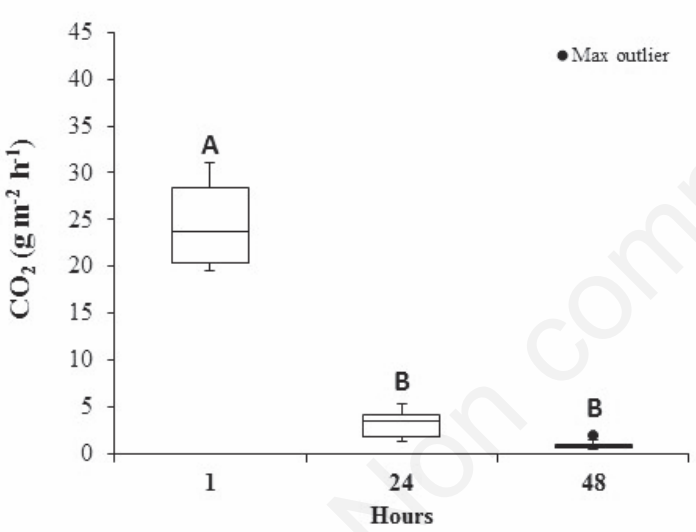

B

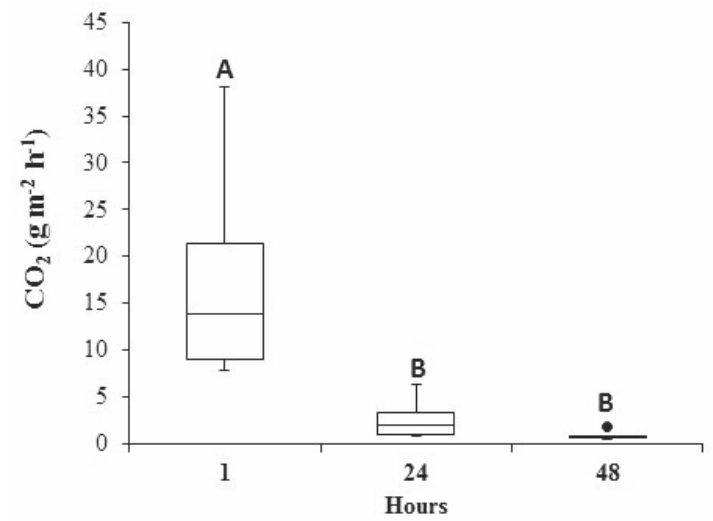

C

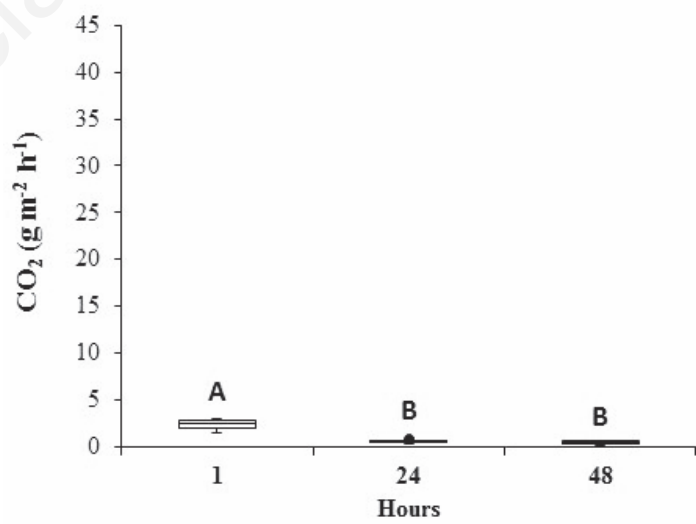

$\mathrm{D}$

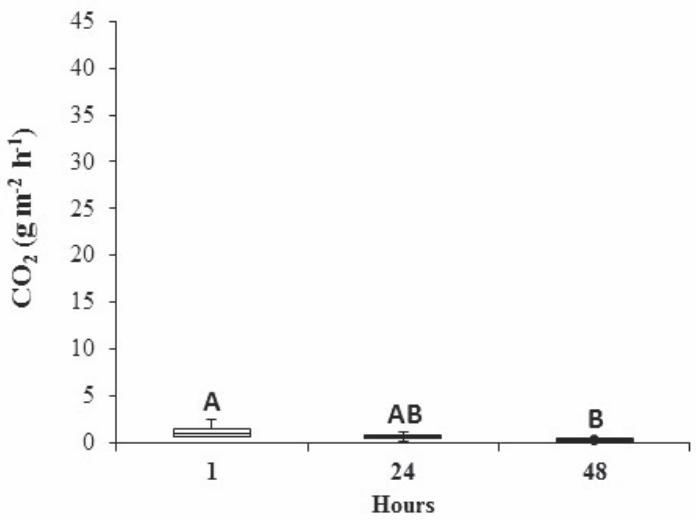

Figure 1. Box-plot diagrams of soil $\mathrm{CO}_{2}$ emissions in the $48 \mathrm{~h}$ after digestate liquid fraction distribution in the experimental treatments. A) Digestate injection at $10 \mathrm{~cm}$ depth; B) digestate injection at $25 \mathrm{~cm}$ depth; C) digestate injection at $35 \mathrm{~cm}$ depth; D) un-amended control. Different letters indicate significant differences at $\mathrm{P}<0.05$ by Kruskal-Wallis test. 
ments. From maize sowing to its harvest, the highest soil $\mathrm{CO}_{2}-\mathrm{C}$ cumulative emission was measured in the $25 \mathrm{~cm}$ treatment (43.6\%) followed by the $35 \mathrm{~cm}(36.1 \%)$ and $10 \mathrm{~cm}(25.4 \%)$ ones. Data obtained suggest that: i) in the short period (from digestate distribution to maize sowing), the $\mathrm{CO}_{2}$-C emission decreases enhancing DLF injection depth; ii) in the long period (from digestate distribution to maize harvest), the lowest $\mathrm{CO}_{2}-\mathrm{C}$ emission was shown by the deepest injection (38.3\%), whereas similar values were found for $10 \mathrm{~cm}(86.8 \%)$ and $25 \mathrm{~cm}$ (87.4\%) which therefore showed the same cumulative $\mathrm{CO}_{2}$-C emission but with different proportions between before and after sowing. Considering $10 \mathrm{~cm}$ and $25 \mathrm{~cm}$ treatments, the data suggest that the injection at $10 \mathrm{~cm}$ is preferable to indirectly reduce $\mathrm{CO}_{2}-\mathrm{C}$ release in the atmosphere because lower tractor power is required for digestate distribution. The emission values showed by DLF injection at $35 \mathrm{~cm}$ depth are indubitably interesting; however to reduce $\mathrm{CO}_{2}$ losses in the atmosphere further studies are needed to compare soil $\mathrm{CO}_{2}$ emission with tractor $\mathrm{CO}_{2}$ emission to inject digestate at different depth.

During maize growing season in the upper $7.5 \mathrm{~cm}$ soil layer, mois-

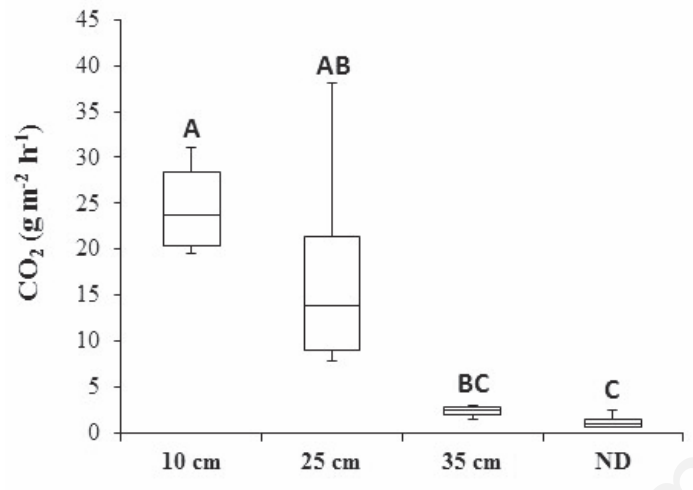

Figure 2. Box-plot diagram of soil $\mathrm{CO}_{2}$ emissions $1 \mathrm{~h}$ after the digestate distribution in the experimental treatments. $10 \mathrm{~cm}$, digestate injection at $10 \mathrm{~cm}$ depth; $25 \mathrm{~cm}$, digestate injection at 25 cm depth; $35 \mathrm{~cm}$, digestate injection at $35 \mathrm{~cm}$ depth; ND, plots without digestate injection. Different letters indicate significant differences at $\mathbf{P}<0.05$ by Kruskal-Wallis test.

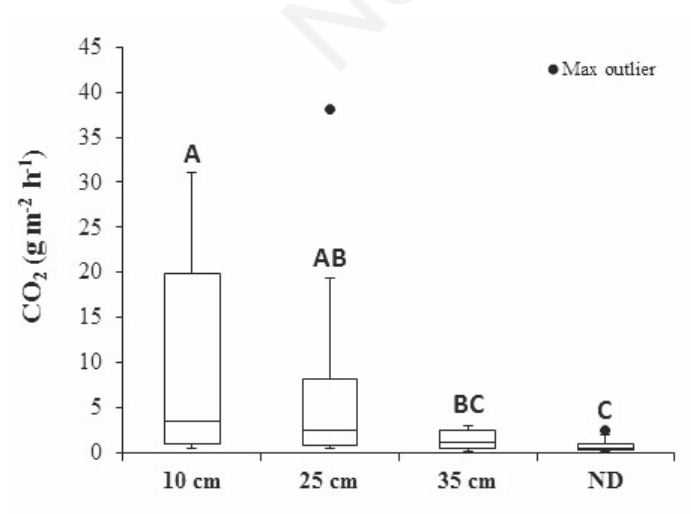

Figure 3. Box-plot diagram of soil $\mathrm{CO}_{2}$ emissions in the $48 \mathrm{~h}$ between digestate distribution and maize sowing in experimental plots. $10 \mathrm{~cm}$, digestate injection at $10 \mathrm{~cm}$ depth; $25 \mathrm{~cm}$, digestate injection at $25 \mathrm{~cm}$ depth; $35 \mathrm{~cm}$, digestate injection at $35 \mathrm{~cm}$ depth; ND, plots without digestate injection. Different letters indicate significant differences at $\mathrm{P}<0.05$ by Kruskal-Wallis test. ture ranged from $11.5 \%$ to $53.2 \%$ and temperature from $19.3^{\circ} \mathrm{C}$ to $33.9^{\circ} \mathrm{C}$. Soil $\mathrm{CO}_{2}$ emission was positively correlated with both soil moisture and temperature (Table 2), supporting the strong direct and indirect effect on organic material decomposition (Sänger et al., 2011) exerted by soil aerobic metabolism. Considering the simultaneous effect of soil moisture and temperature on soil $\mathrm{CO}_{2}$ emissions, the highest emission values were monitored when soil temperature ranged from $32^{\circ} \mathrm{C}$ to $34^{\circ} \mathrm{C}$ and, at the same time, soil moisture from $21 \%$ to $26 \%$. Results are in agreement with Suseela et al. (2012), who found that soil respiration proceeded fastest at the warmest temperatures when soil water content ranged from $20 \%$ to $30 \%$.

\section{Maize biomass production}

DLF distribution significantly (ANOVA, $\mathrm{P}<0.05$ ) improved maize aboveground dry biomass with an average production, in amended and un-amended plots, of $22.0 \mathrm{Mg} \mathrm{ha}^{-1}$ and $16.2 \mathrm{Mg} \mathrm{ha}^{-1}$, respectively. The difference may be attributed to the higher nutrients input received by the amended plots. Maize yield obtained in amended plots is in agreement

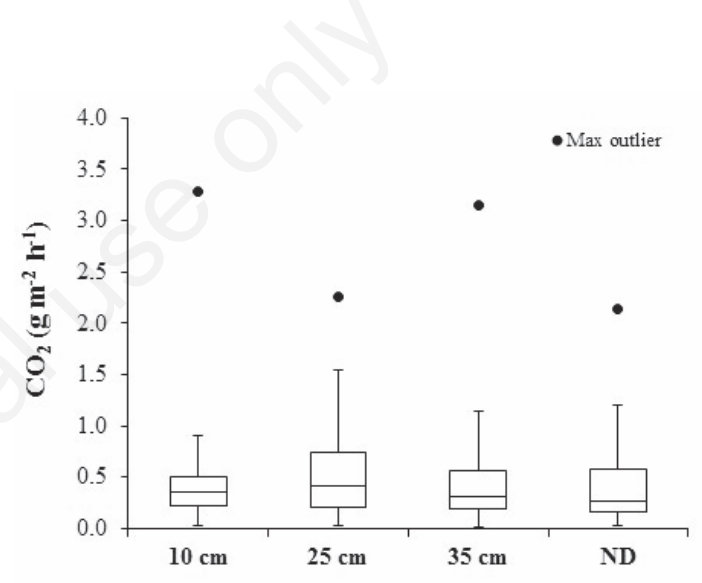

Figure 4. Box-plot diagram of soil $\mathrm{CO}_{2}$ emissions between maize sowing and harvest in experimental plots. $10 \mathrm{~cm}$, digestate injection at $10 \mathrm{~cm}$ depth; $25 \mathrm{~cm}$, digestate injection at $25 \mathrm{~cm}$ depth; $35 \mathrm{~cm}$, digestate injection at $35 \mathrm{~cm}$ depth; ND, plots without digestate injection. Different letters indicate significant differences at $\mathbf{P}<0.05$ by Kruskal-Wallis test.

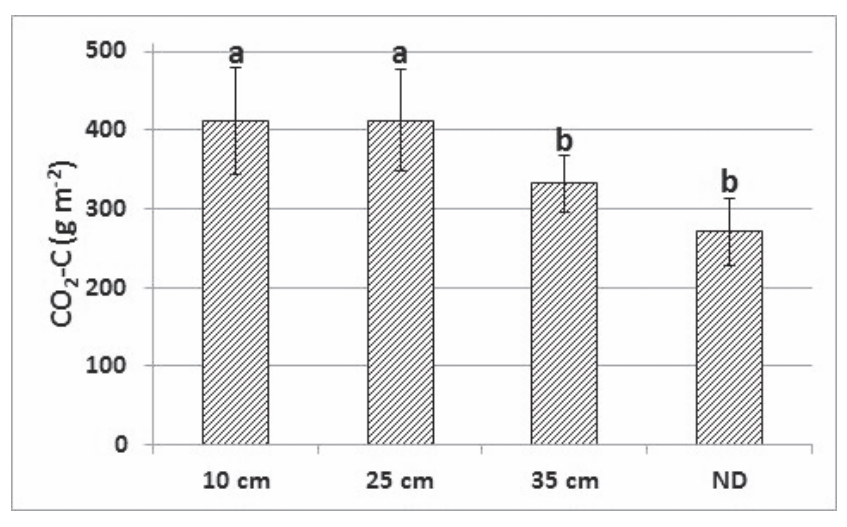

Figure 5. Soil cumulative $\mathrm{CO}_{2}-\mathrm{C}$ emissions during the whole experimental period. $10 \mathrm{~cm}$, digestate injection at $10 \mathrm{~cm}$ depth; $25 \mathrm{~cm}$, digestate injection at $25 \mathrm{~cm}$ depth; $35 \mathrm{~cm}$, digestate injection at $35 \mathrm{~cm}$ depth; ND, plots without digestate injection. Different letters indicate significant differences at $P<0.05$ by Fisher least significant difference test. 
Table 2. Spearman rank correlation of soil $\mathrm{CO}_{2}$ emissions with its temperature and moisture during maize growing season.

\begin{tabular}{lcccc} 
Correlation & $10 \mathrm{~cm}$ & $25 \mathrm{~cm}$ & $35 \mathrm{~cm}$ & $\mathrm{ND}$ \\
$\mathrm{CO}_{2}$ vs temperature & $0.580^{* * *}$ & $0.487^{* * *}$ & $0.595^{* * *}$ & $0.633^{* * *}$ \\
\hline $\mathrm{CO}_{2}$ vs moisture & $0.299^{*}$ & $0.471^{* * *}$ & $0.410^{* *}$ & $0.442^{* * *}$ \\
\hline
\end{tabular}

$10 \mathrm{~cm}$, digestate injection at $10 \mathrm{~cm}$ depth; $25 \mathrm{~cm}$, digestate injection at $25 \mathrm{~cm}$ depth; $35 \mathrm{~cm}$, digestate injection at $35 \mathrm{~cm}$ depth; ND, plots without digestate injection. ${ }^{*} \mathrm{P}<0.05 ;{ }^{* *} \mathrm{P}<0.01 ;{ }^{* * *} \mathrm{P}<0.001$.

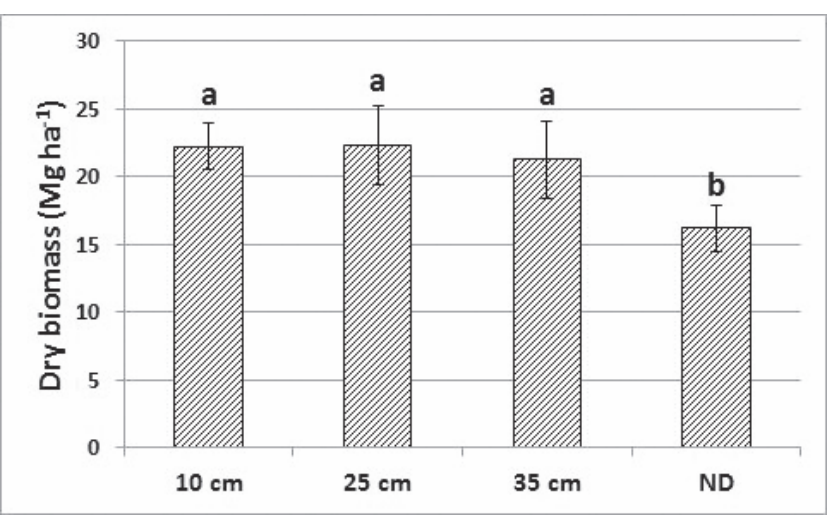

Figure 6. Maize dry biomass production at dough stage. $10 \mathrm{~cm}$, digestate injection at $10 \mathrm{~cm}$ depth; $25 \mathrm{~cm}$, digestate injection at $25 \mathrm{~cm}$ depth; $35 \mathrm{~cm}$, digestate injection at $35 \mathrm{~cm}$ depth; ND, plots without digestate injection. Different letters indicate significant differences at $\mathbf{P}<0.05$ by Fisher least significant difference test.

with our previous data (22.7 $\mathrm{Mg} \mathrm{ha}^{-1}$ ) obtained with DLF splash-plate spreading on a clay loam soil. In our research, maize dry biomass yield was not significant influence by digestate injection depth (Figure 6). Obtained results confirmed that anaerobic digestate could be regarded as effective organic fertilisers (Nkoa, 2014). Furthermore, Walsh et al. (2012) reported that replacing inorganic fertilisers with liquid digestate could maintain or improve yields from grassland systems, with less impact on the environment. Considering only the DLF macronutrients (N, $\mathrm{P}_{2} \mathrm{O}_{5}, \mathrm{~K}_{2} \mathrm{O}$ ), and using the $\mathrm{CO}_{2(\mathrm{eq})}$ specific emission factors for mineral fertilisers production (Capponi et al., 2012), the avoided carbon emission in the atmosphere, in this study, was equivalent to $859.6 \mathrm{~kg}$ $\mathrm{CO}_{2(\mathrm{eq})} \mathrm{ha}^{-1}$.

\section{Conclusions}

The DLF effect on soil $\mathrm{CO}_{2}$ emission followed the same trend for all studied digestate soil injection depths with high emission in the first hour after distribution, and a significant reduction already after $24 \mathrm{~h}$, reaching values similar to un-amended plots after $48 \mathrm{~h}$. Comparing the emissions measured $1 \mathrm{~h}$ after digestate injection, $\mathrm{CO}_{2}$ flux decreased when injection depth increased, with significantly higher emission in the $10 \mathrm{~cm}$ treatment (median value $23.7 \mathrm{~g} \mathrm{CO}_{2} \mathrm{~m}^{-2} \mathrm{~h}^{-1}$ ) and the lowest one in the $35 \mathrm{~cm}$ treatment (median value $2.5 \mathrm{~g} \mathrm{CO}_{2} \mathrm{~m}^{-2} \mathrm{~h}^{-1}$ ). During maize growing season, no significant soil $\mathrm{CO}_{2}$ emission difference was monitored among treatments, with a median value of $0.33 \mathrm{~g} \mathrm{CO}_{2} \mathrm{~m}^{-2} \mathrm{~h}^{-1}$.

A significantly higher cumulative soil $\mathrm{CO}_{2}-\mathrm{C}$ emission during the experimental period was found for $10 \mathrm{~cm}$ and $25 \mathrm{~cm}$ treatments, with an average value of $411.8 \pm 63.6 \mathrm{~g} \mathrm{CO}_{2}-\mathrm{C} \mathrm{m}^{-2}$; no significant difference was found between $35 \mathrm{~cm}$ and ND treatments, with an average value of $301.3 \pm 49.0 \mathrm{~g} \mathrm{CO}_{2}-\mathrm{C} \mathrm{m}^{-2}$.

Our results clearly showed that increasing DLF injection depth soil $\mathrm{CO}_{2}-\mathrm{C}$ flux decreases. This suggests that for maize sown as second crop in late spring, a potential containment of $\mathrm{CO}_{2}$ emission can be achieved through deep injection associated with tillage, i.e., one pass strategy with a chisel equipped with tank and nozzles.

Digestate liquid fraction presents fertiliser properties indicating the possibility to reduce the use of mineral fertilisers with a consequent reduction of energy use and $\mathrm{CO}_{2(\mathrm{eq})}$ emissions for their production.

\section{References}

Alburquerque JA, de la Fuente C, Bernal MP, 2012a. Chemical properties of anaerobic digestates affecting $\mathrm{C}$ and $\mathrm{N}$ dynamics in amended soils. Agric. Ecosyst. Environ. 160:15-22.

Alburquerque JA, de la Fuente C, Ferrer-Costa A, Carrasco L, Cegarra J, Abad M, Bernal MP, 2012b. Assessment of the fertiliser potential of digestates from farm and agroindustrial residues. Biomass. Bioenerg. 40:181-9.

Bachmann S, Gropp M, Eichler-Löbermann B, 2014. Phosphorus availability and soil microbial activity in a 3 year field experiment amended with digested dairy slurry. Biomass. Bioenerg. 70:429-39.

Barbera AC, Maucieri C, Cavallaro V, Ioppolo A, Spagna G, 2013. Effects of spreading olive mill wastewater on soil properties and crops, a review. Agr. Water Manage. 119:43-53.

Bol R, Moering J, Kuzyakov Y, Amelung W, 2003. Quantification of priming and $\mathrm{CO}_{2}$ respiration sources following slurry $\mathrm{C}$ incorporation into two grassland soils with different $\mathrm{C}$ content. Rapid Commun. Mass Spectrom. 17:2585-90.

Borin M, Giupponi C, Morari F, 1997. Effects of four cultivation systems for maize on nitrogen leaching 1. Field experiment. Eur. J. Agron. 6:101-12.

Casacchia T, Sofo A, Zelasco S, Perri E, Toscano P, 2012. In situ olive mill residual co-composting for soil organic fertility restoration and by-product sustainable reuse. Ital. J. Agron. 7:167-70.

Capponi S, Fazio S, Barbanti L, 2012. $\mathrm{CO}_{2}$ savings affect the break-even distance of feedstock supply and digestate placement in biogas production. Renew. Energy 37:45-52.

Cayuela ML, Oenema 0, Kuikman PJ, Bakker RR, Van Groenigen JW, 2010. Bioenergy by products as soil amendments? Implications for carbon sequestration and greenhouse gas emissions. GCB Bioenergy 2:201-13.

de la Fuente C, Alburquerque JA, Clemente R, Bernal MP, 2013. Soil C and $\mathrm{N}$ mineralisation and agricultural value of the products of an anaerobic digestion system. Biol. Fert. Soils 49:313-22.

Dieterich B, Finnan J, Frost P, Gilkinson S, Müller C, 2012. The extent of methane $\left(\mathrm{CH}_{4}\right)$ emissions after fertilisation of grassland with digestate. Biol. Fert. Soils 48:981-85.

Ding W, Cai Y, Cai Z, Zheng X, 2006. Diel pattern of soil respiration in $\mathrm{N}$ amended soil under maize cultivation. Atmos. Environ. 40:3294-305.

Fangueiro D, Chadwick D, Dixon L, Grilo J, Walter N, Bol R, 2010. Short term $\mathrm{N}_{2} \mathrm{O}, \mathrm{CH}_{4}$ and $\mathrm{CO}_{2}$ production from soil sampled at different depths and amended with a fine sized slurry fraction. Chemosphere 81:100-108.

Grigatti M, Di Girolamo G, Chincarini R, Ciavatta C, Barbanti L, 2011. Potential nitrogen mineralisation, plant utilization efficiency and soil $\mathrm{CO}_{2}$ emissions following the addition of anaerobic digested slurries. Biomass. Bioenerg. 35:4619-29.

Holm-Nielsen JB, Al Seadi T, Oleskowicz-Popiel P, 2009. The future of 
anaerobic digestion and biogas utilization. Bioresour. Technol. 100:5478-84.

Johansen A, Carter MS, Jensen ES, Hauggard-Nielsen H, Ambus P, 2013. Effects of digestate from anaerobically digested cattle slurry and plant materials on soil microbial community and emission of $\mathrm{CO}_{2}$ and $\mathrm{N}_{2} \mathrm{O}$. Appl. Soil Ecol. 63:36-44.

Lou Y, Li Z, Zhang T, 2003. Carbon dioxide flux in a subtropical agricultural soil of China. Water Air Soil Poll. 149:281-93.

Marchetti R, Castelli F, Orsi A, Sghedoni L, Bochicchio D, 2012. Biochar from swine manure solids: influence on carbon sequestration and Olsen phosphorus and mineral nitrogen dynamics in soil with and without digestate incorporation. Ital. J. Agron. 7:189-95.

Maucieri C, Borin M, Barbera AC, 2014. Role of C3 plant species on carbon dioxide and methane emissions in Mediterranean constructed wetland. Ital. J. Agron. 9:120-6.

Möller K, Müller T, 2012. Effects of anaerobic digestion on digestate nutrient availability and crop growth: a review. Eng. Life Sci. 12:242-57.

Morari F, Lugato E, Berti A, Giardini L, 2006. Long term effects of recommended management practices on soil carbon changes and sequestration in north eastern Italy. Soil Use Manage. 22:71-81.

Morra L, Pizzolongo G, Baiano S, Pentangelo A, 2013. Comparison of olive pomace and biowaste composts in a vegetable cropping system. Ital. J. Agron. 8:206-16.

Nardi S, Morari F, Berti A, Tosoni M, Giardini L, 2004. Soil organic matter properties after 40 years of different use of organic and mineral fertilisers. Eur. J. Agron. 21:357-67.

Nkoa R, 2014. Agricultural benefits and environmental risks of soil fertilization with anaerobic digestates: a review. Agron. Sustain. Dev. 34:473-92.
Paustian K, Six J, Elliott ET, Hunt HW, 2000. Management options for reducing $\mathrm{CO}_{2}$ emissions from agricultural soils. Biogeochemistry 48:147-63.

Petersen SO, 1999. Nitrous oxide emissions from manure and inorganic fertilizers applied to spring barley. J. Environ. Qual. 28:1610-8.

Pezzolla D, Bol R, Gigliotti G, Sawamoto T, López AL, Cardenas L, Chadwick D, 2012. Greenhouse gas (GHG) emissions from soils amended with digestate derived from anaerobic treatment of food waste. Rapid Commun. Mass Spectrom. 26:2422-30.

Rochette P, Flanagan LB, 1997. Quantifying rhizosphere respiration in a corn crop under field conditions. Soil Sci. Soc. Am. J. 61:466-74.

Rubæk GH, Henriksen K, Petersen J, Rasmussen B, Sommer SG, 1996. Effects of application technique and anaerobic digestion on gaseous nitrogen loss from animal slurry applied to ryegrass (Lolium perenne). J. Agr. Sci. 126:481-92.

Sänger A, Geisseler D, Ludwig B, 2011. Effects of moisture and temperature on greenhouse gas emissions and $\mathrm{C}$ and $\mathrm{N}$ leaching losses in soil treated with biogas slurry. Biol. Fert. Soils 47:249-59.

Suseela V, Conant RT, Wallenstein MD, Dukes JS, 2012. Effects of soil moisture on the temperature sensitivity of heterotrophic respiration vary seasonally in an old field climate change experiment. Glob. Change Biol. 18:336-48.

Walsh JJ, Jones DL, Edwards Jones G, Williams, AP, 2012. Replacing inorganic fertilizer with anaerobic digestate may maintain agricultural productivity at less environmental cost. J. Plant Nutr. Soil Sc. 175:840-5.

Wulf S, Maeting M, Clemens J, 2002. Application technique and slurry co-fermentation effects on ammonia, nitrous oxide, and methane emissions after spreading. J. Environ. Qual. 31:1795-801. 